UDC 614.2.007

DOI: $10.21668 /$ health.risk/2017.1.14.eng

\title{
PERSONNEL POLICY IN HEALTHCARE: RISKS AND SOLUTIONS
}

\section{E.Ya. Titova}

Perm State Medical University named after E.A. Wagner, 26 Petropavlovskaya Str., Perm, 614000, Russian Federation

We studied the dynamics of Perm region population provision with medical personnel over 2006-2015 basing on the official statistics data; the parameter was compared with the average level in the Russian Federation. We detected that provision of Perm region population with physicians and paramedics was higher than average Russian level in the stated period; however, a negative dynamics in parameters occurred and there is still personnel deficiency. A doctors-paramedics ratio improved a bit but it was still lower than in the $R F$ on average and lower than the recommended level. Staffing of physicians' jobs with people decreased a bit in the examined period while staffing of paramedics' jobs, on the contrary, grew up. Also there was a decrease in a number of physicians and paramedics' who combined jobs. Specific weight of certified medical staff was higher in Perm region than in the country on average. Changes which occurred in medical staff distribution as per categories prove that the share of senior age groups increased both among physicians and paramedics. There is a disproportion in provision with physicians and paramedics in terms of various territories in Perm region, and it requires systemic targeted activities of all concerned structures. A system of admission to medical HEEs and colleges needs to be reformed so that applicants could avoid making a mistake in their career choice; it is also necessary to work out a set of measures aimed at raising prestige of a physician' and paramedic's job as well as pay greater attention to social security of medical staff.

Key words: availability and quality of medical aid, personnel policy, provision with doctors, provision with nurses, staffing, combining jobs, trend, disproportion in distribution, prestige of a physician' and paramedic's job, social security.

Nowadays public health care in Russia faces a most serious task as it has to increase availability and quality of medical aid. And sufficient quantity of well-qualified medical personnel is the basic condition which can help to solve it $[1-7,9,10,14,15]$.

There is deficiency in Russian public health care in terms of doctors and nurses [3, $5,8,14]$. As per data given by the RF Public Health Ministry, 148,200 doctors are required in Russia, and only 52,000 graduate from medical HEEs annually. Also every year 22,000 doctors retire, and $10 \%$ doctors are close to the age of retirement or are already of that age [6]. Personnel deficiency is primarily caused by insufficient inflow of young specialists in the field. It is medical HEE graduates who are one of the most vulnerable categories. If we consider losses of medical personnel in the field we can see that $22 \%$ of medical students plan to go abroad to get further education, and $11 \%$ don't have any intention to work in a medical establishment after graduation. Only $21 \%$ of doctors who are younger than 35 , and $17 \%$ of medical HEE graduates consider it possible to work in rural areas and remote regions [14]. More than 800,000 nurses are required in the country. Annually almost 90,000 paramedics quit public health care (and deficiency in them being 280,000), and only 15,000 of that number actually retire; every year only 50,000 young specialists finish their education and enter the field [6].

Ratio between doctors and paramedics

(C) Titova E.Ya., 2017

Elena Ya. Titova - associate professor at Public health and Healthcare Department, candidate of medical sciences (e-mail:etitova55@yandex.ru; tel.: +7(912)784-55-21). 
quantities in our country is significantly lower than in most developed countries in the world and it leads to imbalance in medical aid system and restricts possibilities to develop aftercare services, nursing, and rehabilitation $[2,8,9$, 14]. In Russia there are 1.8 nurses per 1 doctor on average [13], but the required minimum is $3-4$, and therefore doctors have to perform additional functions $[2,6]$.

There is also a significant disproportion in medical personnel distribution, as per urban and rural areas, in-patient hospitals and out-patient one and polyclinics, as well as in terms of various medical specialties $[2,3,6,7,9,14]$. In relation to that a number of authors assume it would be advisable to return to a system of planned graduates distribution $[2,13]$.

Average salary of doctors in Russia is $22 \%$ lower than average salary in the country. While in so called "new" EU countries doctors get 1.5-2.5 times higher salary than on average [2]. More than 55\% doctors say they are dissatisfied with their salary [7]; $80 \%$ quit public health because of low salary [6]. The President of the RF set a task to increase doctors' salary up to $200 \%$ of average salary in a region in 2018 [13]. However, we don't have clear understanding of how many staff jobs one doctor will have to take to get such salary.

In the course of our research we detected that $47 \%$ nurses had workload higher than standard due to internal jobs combining; $19 \%$ combined jobs externally; $35 \%$ had more duties than set forth in standards. And at that $59 \%$ nurses had constant lack of sleep. 12\% questioned nurses said they slept less than 6 hours a night. And low salary was one of the major reasons for increased and excessive workload [11].

More than $30 \%$ of population don't think a doctor's occupation is prestigious. And only $20 \%$ of doctors themselves think their social status is high [7]. A medical worker status, doctors included, is gradually losing its former popularity [14].

As a problem of medical personnel staffing in state and municipal public health care is a truly burning one, the RF Public Health Ministry issued the Order No.210, dated July, 03,
2002 which adopted "The Personnel Policy Concept in the RF Public Health Care". The concept determined basic issues in human resources management in the field and set forth major tasks aimed at its implementation.

Our research goal was to examine and assess dynamics of population provision with medical personnel in Perm region over 20062015 and then work out propositions on increasing efficiency of personnel policy in public health care.

Data and methods. We examined the dynamics of population provision with medical personnel in Perm region over 2006-2015 in comparison with average country indices basing on the official statistic data. We calculated average chronological values of dynamics rows and their errors, as well as increase rates. To determine trends, we accomplished rows equalization as per moving average.

Results and discussion. Our research revealed that from 2006 to 2015 provision with doctors in Perm region was a bit higher than in the RF as a whole. Indices varied from 39.1 to 49.0 per 10,000 people correspondingly. Average chronological value in Perm region amounted to $45.9 \pm 3.1$ against $42.6 \pm 2.4$ in Russia.

We also detected significant discrepancies in indices dynamics. In the RF there was a slight but constant growth in the index up to 2009 (by $0.9-0.7 \%$ ), and only starting from 2011, a decrease appeared (2012 and 2015 were exceptions with the growth by 1.8 and $0.3 \%$ correspondingly). But in Perm region a decrease in provision with doctors was practically constant (2009 and 2011 were exceptions, with 1.0 and $1.7 \%$ growth correspondingly).

2014 was a distinctive one, when provision with doctors dropped greatly, both in Perm region and in the RF (by 14.4 and $16.1 \%$ correspondingly). The index in the RF grew by $0.3 \%$, but it remained steady in Perm region (figures 1 and 2). We detected a disproportion in provision with doctors in Perm region territories. For example, in 2015 indices varied from 40.2 (in Perm) to 18.1 (in Alexandrovsk); as for rural areas, from 30.5 (in Chstinskiy dis- 
trict) to 10.1 (in Cherdyinskiy district). Loss of doctors occurred in 21 territories out of 47 only over 1 year (in 2014 it occurred only in 13 territories).

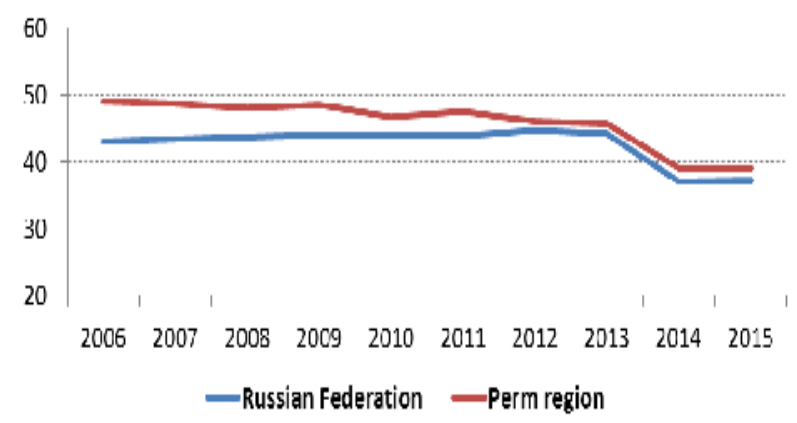

Figure 1. Provision with doctors (per 10,000 people)

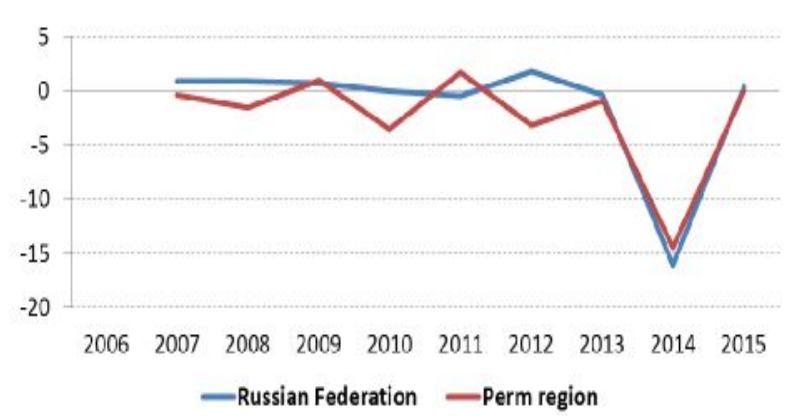

Figure 2. Increase rate in provision with doctors $(\%)$

Moving average calculation showed that there was a persistent trend of decrease in provision with doctors in Perm region in the examined period as opposed to the RF as a whole (Figure 3).

So, in 2015, in comparison with 2006, provision with doctors in Perm region declined by $20.2 \%$, but in the RF it dropped by $13.5 \%$ only. The indices amounted to 39.1 and 37.2 per 10,000 people correspondingly, and it was lower than the planned values (42.4 and 40.2 per 10,000 people).

Provision with paramedics over the examined period was also higher in Perm region (from 86.7 to 104.3 per 10,000 people), than in the RF (from 89.6 to 95.0). And only in 2015 the index in Perm region became lower than in the $\mathrm{RF}$ as a whole (86.7 against 89.6 per 10,000 people). Average chronological value in the examined period in Perm region amounted to $95.9 \pm 5.7$ per 10,000 people against $92.7 \pm 1.7$.

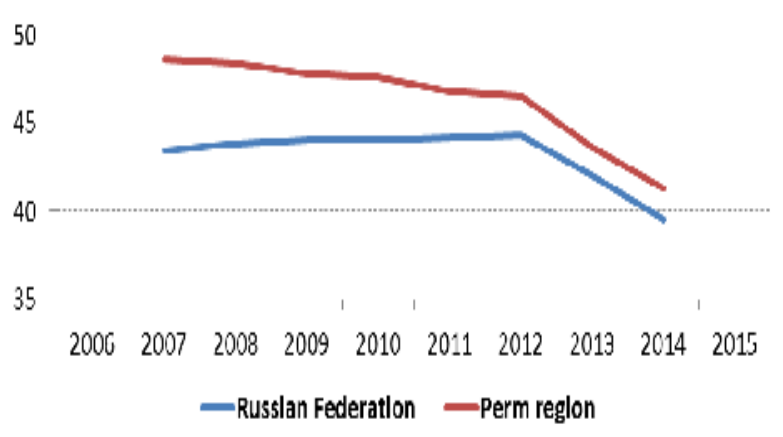

Figure 3. Moving average of provision with doctors (per 10,000 people)

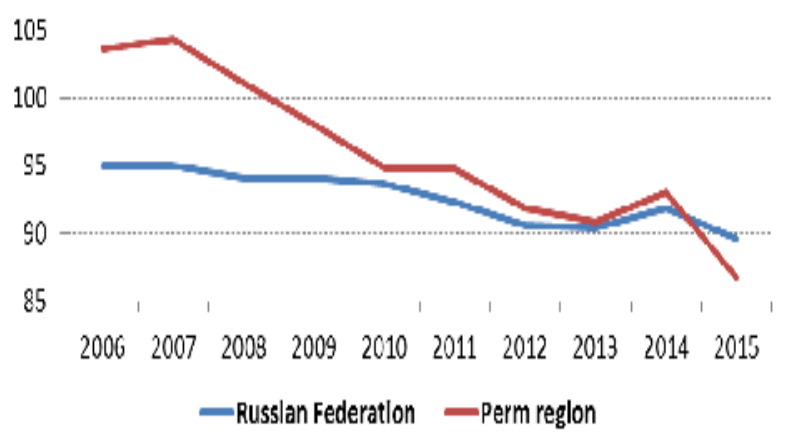

Figure 4. Provision with paramedics (per 10,000 people)

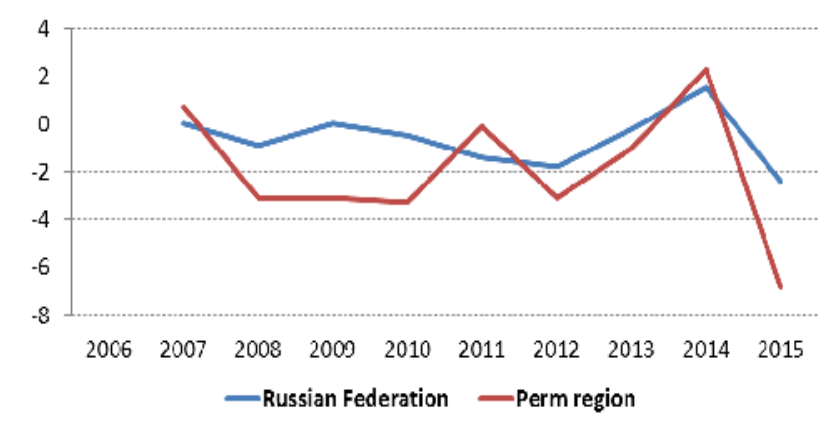

Figure 5. Increase rate in provision with paramedics (\%)

2014 was a bit different when the biggest growth in the index occurred both in Perm region and in the $\mathrm{RF}$ (by 2.3 and $1.5 \%$ correspondingly). In 2015, on the contrary, the greatest decrease in provision with paramedics 
occurred (by 6.8 and $2.4 \%$ correspondingly) (figures 4 and 5).

We detected a considerable disproportion in provision with paramedics in Perm region: thus, in 2015 it varied in urban areas from 110.1 (in Chaikovskiy) to 60.2 (in Perm); in rural areas, from 118.6 (in Uinskiy district) to 48.1 (in Kungurskiy district). Loss of paramedics over one year occurred in 33 territories.

Moving average calculation revealed that there was a quite persistent trend of decrease in provision with paramedics not only in Perm region but also in the RF as a whole, as opposed to provision with doctors. However, the decrease was more rapid in Perm region (figure 6).

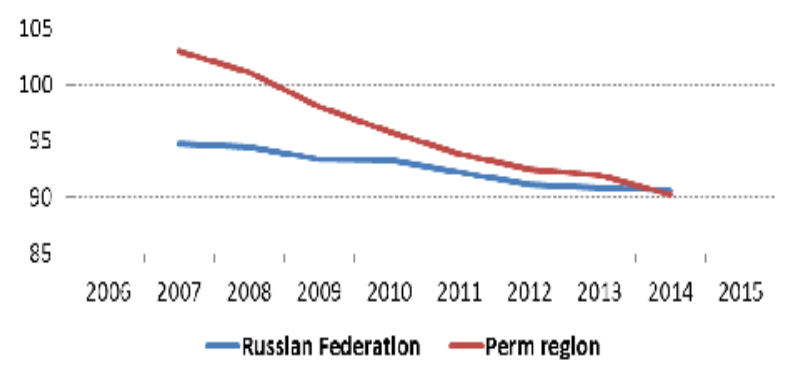

Figure 6. Moving average of provision with paramedics (per 10,000 people)

So, provision with paramedics in Perm region decreased by $16.3 \%$ in 2015 in comparison with 2006; it decreased only by $5.7 \%$ in the RF (table).

Ratio between doctors and paramedics in Perm region improved a bit over the examined period (from 1:2.1 in 2006 to 1:2.2 in 2015). And still it was lower than in the RF (1: 2.2 in $2006 ; 1: 2.4$ in 2015) and lower than recommended level $(1: 3 ; 1: 4)[2,6]$.

Staffing of doctor jobs with individuals decreased a bit over the examined period, from $62.5 \%$ in 2006 to $61.6 \%$ in 2015. Staffing of paramedics jobs on the contrary increased from 70.0 to $70.1 \%$ correspondingly. Coefficient showing jobs combining over the examined period decreased both for doctors and paramedics (from 1.52 to $1.44 \%$ and from 1.38 to $1.31 \%$ correspondingly).
Specific weight of certified medical personnel in Perm region is higher than on average in the RF. Over the examined period specific weight of certified doctors decreased by $0.8 \%$ (from 61.9 to $61.4 \%$ ), but specific weight of certified paramedics, on the contrary, grew by $5.6 \%$ (from 69.5 to $73.4 \%$ ). And these indices in 2015 were higher than the same ones in the RF (48.4 and $55.4 \%$ correspondingly). It is interesting to note that specific weight of doctors and paramedics having the highest qualification degree grew in both occupational groups whereas specific weight of personnel with the first and second category went down. It indirectly implies that the share of medical personnel belonging to senior age group grows. Specific weight of certified doctors grew by $57.3 \%$ from 2006 to 2015 (from 63.0 to $99.1 \%$ ), and specific weight of certified paramedics also went up by $50.3 \%$ (from 65.6 to $98.6 \%$ ), and it was higher than in the RF in 2015 (98.3 and $93.4 \%)$.

We conducted sociological research among 5th year students of Pediatric Faculty, Perm State Medical University; its results revealed that only $86 \%$ respondents wanted to pursue a doctor's career after graduation. As for the remaining share, only $68 \%$ of them had clear vision of their future professional activities [12]. As per data given by Yu. Komarov [6], almost $30 \%$ graduates quit medicine.

Only $40 \%$ respondents had at least some idea of activities implemented at federal and regional levels and aimed at solving personnel problems in public health care. $80 \%$ respondents gave their own ideas on how to solve them; the first place belonged to increase in doctors' salaries (44\%), better working conditions took the second place (20\%) and respondents included providing hospitals with up-to-date equipment into this idea; housing provision occupied the third place (11\%); 3\% respondents offered to return to graduates distribution after they finished studying at HEEs [12]. 


\section{Conclusions:}

1. Although provision of Perm region population with doctors and paramedics was higher than on average in the RF in 20062015 , indices dynamics was unfavorable and there is still personnel deficiency.

The results of personnel policy implementation in Perm region in 2015 in comparison with 2006

\begin{tabular}{|l|c|c|c|c|c|c|}
\hline \multirow{2}{*}{\multicolumn{1}{|c|}{ Index }} & \multicolumn{3}{c|}{ Doctors } & \multicolumn{3}{c|}{ Paramedics } \\
\cline { 2 - 7 } & 2006 & 2015 & $\begin{array}{c}\text { Increase / } \\
\text { decrease rate, } \%\end{array}$ & 2006 & 2015 & $\begin{array}{c}\text { Increase / } \\
\text { decrease rate, \% }\end{array}$ \\
\hline Provision, per 10,000 population & 49,0 & 39,1 & $-20,2$ & 103,6 & 86,7 & $-16,3$ \\
\hline Staffing with individuals, \% & 62,5 & 61,6 & $-1,44$ & 70,0 & 70,1 & 0,1 \\
\hline Coefficient of jobs combining & 1,52 & 1,44 & $-5,3$ & 1,38 & 1,31 & $-5,1$ \\
\hline $\begin{array}{l}\text { Specific weight of certified personnel, } \\
\%\end{array}$ & 61,9 & 61,4 & $-0,8$ & 69,5 & 73,4 & 5,6 \\
\hline $\begin{array}{l}\text { Specific weight of personnel with cer- } \\
\text { tificates, \% }\end{array}$ & 63,0 & 99,1 & 57,3 & 65,6 & 98,6 & 50,3 \\
\hline
\end{tabular}

2 . The ratio between doctors and paramedics over the examined period improved a bit, but still it remained lower than in the RF as a whole, and lower than recommended.

3. Staffing of doctors' jobs with individuals decreased slightly over the examined period, but staffing of paramedics' jobs on the contrary increased. And also coefficient showing jobs combining went down in both occupational groups.

4. Specific weight of certified medical personnel and personnel with certificates is a bit higher than in the RF as a whole. Changes which occurred in distribution of medical personnel as per categories reveal that a share of medical personnel from senior age groups grew, both among doctors and paramedics.
5. There is a disproportion in provision with doctors and paramedics in various territories of Perm region, and it requires systemic and targeted efforts of all concerned structures.

6. To solve personnel problems in public health care, we need to reform system of admission to medical HEEs and colleges so that applicants could avoid making mistakes when choosing a career; we also need to work out a set of activities aimed at making doctors' and paramedics' occupations more prestigious as well as at raising their social security.

7. Issues of personnel policy, labor motivation, ratio between number and structure of doctors and paramedics require permanent monitoring and profound analysis both at federal and regional level.

\section{References}

1. Boyarskii S.G. Kontseptsiya razvitiya rossiiskogo zdravookhraneniya: problemy obespecheniya kadrami v sfere organizatsii zdravookhraneniya i obshchestvennogo zdorov'ya [Concept of the Health Care Development in Russia: Problems of Staffing in Health Care Management and Public Health]. Meditsinskie tekhnologii. Otsenka i vybor, 2010, no. 2, pp. 54-58 (in Russian).

2. Kostin A.A., Ponomarenko B.T., Samsonov Yu.V. Gosudarstvennaya kadrovaya politika v sfere zdravookhraneniya. Nauchnoe izdanie [State personnel policy in healthcare. Scientific edition]. Moscow, Mezhdunarodnyi izdatel'skii tsentr «Etnosotsium» Publ., 2015, 96 p. (in Russian).

3. D'yachenko V.G., D'yachenko S.V., Prigornev V.B. Kadry zdravookhraneniya. Krivoe zerkalo statistiki [Health workforce. Distorting mirror of statistics]. Vestnik obshchestvennogo zdorov'ya $i$ zdravookhraneniya Dal'nego Vostoka Rossii, 2013, vol. 13, no. 4, pp. 3 (in Russian).

4. Zimina E.V. Sistemnost' podgotovki upravlencheskikh kadrov zdravookhraneniya kak faktor obespecheniya kachestva meditsinskoi pomoshchi [System approach in healthcare management training as a factor providing medical aid quality]. Vestnik Roszdravnadzora, 2010, no. 1, pp. 52-57 (in Russian). 
5. Kleimenova L.V. Osnovnye kadrovye problemy $\mathrm{v}$ sfere zdravookhraneniya goroda Bratska [Main personnel problems in public health service in the city of Bratsk]. Problemy sotsial'noekonomicheskogo razvitiya Sibiri, 2014, vol. 15, no. 1, pp. 42-44 (in Russian).

6. Komarov Yu. O podgotovke vrachebnykh kadrov v Rossiiskoi Federatsii [On Training of Medical Staff in Russian Federation]. Meditsina, 2013, no.3, pp. 1-11(in Russian).

7. Otstavnykh D.V. Problemy kadrovogo obespecheniya otrasli zdravookhraneniya v sovremennykh usloviyakh [Contemporary issues of staff provision in healthcare]. Vestnik obshchestvennogo zdorov'ya i zdravookhraneniya Dal'nego Vostoka Rossii, 2012, vol. 9, no. 4, pp. 5 (in Russian).

8. Savinkina L.A., Shepelova T.S. Problemy defitsita meditsinskikh kadrov i puti ikh resheniya [Scarcity of health workers and its solutions]. Sovremennye problemy nauki i obrazovaniya, 2014, no. 6, pp. 569 (in Russian).

9. Starodubov V.I., Mikhailova Yu.V., Leonov S.A. Kadrovye resursy zdravookhraneniya Rossiiskoi Federatsii: sostoyanie, problemy i osnovnye tendentsii razvitiya [Human resources for health in the Russian Federation: a condition, problems and basic tendencies of developmen]. Sotsial'nye aspekty zdorov'ya naseleniya, 2010, vol. 13, no. 1, pp. 2 (in Russian).

10. Taova S.M. Napravleniya razvitiya kadrovoi politiki v rossiiskom zdravookhranenii [Development trends in personnel policy in Russian healthcare]. Zhurnal nauchnykh publikatsii aspirantov $i$ doktorantov, 2013, vol. 87, no. 9, pp. 6-9 (in Russian).

11. Titova E.Ya., Konovalova N.V. O nekotorykh aspektakh upravleniya zdorov'em personala [On some aspects of managing personnel health]. Problemy ekonomiki, organizatsii $i$ upravleniya $v$ Rossii $i$ mire: materialy VI Mezhdunarodnoi nauchno-prakticheskoi konferentsii [Issues of economy, organization and management in Russia and worldwide: materials of VI International theoretical and practical conference]. Praga, WORDLPRESSsr.o. Publ., 2014, pp. 224-225 (in Russian).

12. Titova E.Ya., Sycheva A.E. O nekotorykh aspektakh kadrovoi politiki [On some aspects of personnel policy]. Problemy ekonomiki, organizatsii $i$ upravleniya $v$ Rossii $i$ mire: materialy IX Mezhdunarodnoi nauchno-prakticheskoi konferentsii [Issues of economy, organization and management in Russia and worldwide: materials of VI International theoretical and practical conference]. Praga, $\begin{array}{lllll}\text { WORDLPRESSsr.o. } & \text { Publ., } & \text { 2015, } & \text { 284-286 }\end{array}$ (in Russian).

13. Sheiman I.M., Shevskii V.I. Kadrovaya politika v zdravookhranenii: sravnitel'nyi analiz rossiiskoi i mezhdunarodnoi praktiki [Health labor policy: comparative analysis of Russian and international developments]. Voprosy gosudarstvennogo i munitsipal'nogo upravleniya, 2015, no. 1, pp. 143-167 (in Russian).

14. Shchepin V.O. Obespechennost' naseleniya Rossiiskoi Federatsii osnovnym kadrovym resursom gosudarstvennoi sistemy zdravookhraneniya [The provision of population of the russian federation with basic personnel resource of public health care system]. Problemy sotsial'noi gigieny, zdravookhraneniya $i$ istorii meditsiny, 2013, no. 6, pp. 24-28 (in Russian).

15. Shchepin O.P., Korotkikh R.V. Perspektivy razvitiya zdravookhraneniya Rossiiskoi Federatsii [The perspectives of development of health care of the Russian Federation]. Problemy sotsial'noi gigieny, zdravookhraneniya i istorii meditsiny, 2015, vol. 23, no. 6, pp. 3-6 (in Russian).

Titova E.Ya. Personnel policy in healthcare: risks and solutions. Health Risk Analysis, 2017, no. 1, pp. 118-123. DOI: 10.21668/health.risk/2017.1.14.eng

Received: 12.12 .2016

Accepted: 18.03 .2017

Published: 30.03 .2017 